\title{
EXTRACTION OF LIPID PROFILE COMPONENTS FROM PLASMA BY VARIOUS FORMS OF POLYMERIC SORBENTS WITH THE AMMONIUM AND PHOSPHONIUM BASE GROUPS
}

\section{ИЗВЛЕЧЕНИЕ КОМПОНЕНТОВ ЛИПИДНОГО СПЕКТРА ИЗ ПЛАЗМЫ РАЗЛИЧНЫМИ ФОРМАМИ ПОЛИМЕРНЫХ СОРБЕНТОВ С ГРУППАМИ АММОНИЕВЫХ И ФОСФОНИЕВЫХ ОСНОВАНИЙ}

\author{
DORSKAIA, Elena V. ${ }^{1 *}$; LEYKIN, Yuri A. ${ }^{1}$; PESTOV, Sergei M. ${ }^{2}$; KOVALENKO, Aleksei E. ${ }^{1}$ \\ 1Dmitry Mendeleev University of Chemical Technology of Russia, Department of Expert Examination in Drug \\ Testing and Narcoanalysis \\ 20 Geroyev Panfilovtsev St., Moscow, 125480, Russian Federation
}

${ }^{2}$ Moscow Technological University, Department of Physical Chemistry

86 Vernadsky Ave., Moscow, 119454, Russian Federation
* Corresponding author
edrhtu@mail.ru

\section{RESUMO}

As doenças cardiovasculares são as principais causas de morte no mundo. O objetivo do artigo é revelar as formas de trocadores de ânions com grupos de bases de amônio e fosfônio, que são os mais promissores para a extração seletiva de colesterol de lipoproteínas de baixa e muito baixa densidade (LDL e VLDL), sendo seu conteúdo elevado um fator derisco para doenças do sistema circulatório. Esta pesquisa é de importância prática, considerando insuficiente seletividade e os efeitos colaterais de sorventes comerciais. $O$ principal método aplicado é a triagem de vários sorventes por parâmetros de sorção de componentes do perfil lipídico para revelar amostras ótimas para remoção de LDL e VLDL.Foi realizada uma análise comparativa das características de sorção pelos componentes do perfil lipídico para trocadores de ânions com grupos de bases de ônio (amônio e fosfônio) em três formas: hidroxila, cloreto e bicarbonato. A capacidade sorvente para os componentes do perfil lipídico (até 5,65 $\mu \mathrm{mol} / \mathrm{g}$ por LDL e VLDL), bem como os fatores de eficiência de sorção, foram encontrados (o coeficiente de seletividade LDL e VLDL foi de até 6,06). A capacidade dos sorventes para influenciar a aterogenicidade do plasma foi caracterizada. As formas mais promissoras de trocadores aniônicos para sorção seletiva de lipídios foram definidas: em geral, estas eram formas $\mathrm{OH}$. O sorvente com grupos base de amônio possui maior capacidade de sorção e um sorvente com grupos fosfônio-base possui maior seletividade para LDL aterogênico e VLDL.Os dados do artigo podem ser úteis no desenvolvimento e na aplicação prática de colunas de sorção para remoção seletiva de colesterol LDL e VLDL com efeitos colaterais mínimos.

Palavras-chave: adsorção de plasma, sorventes de plasma, sorção de colesterol, remoção seletiva de colesterol, sorção lipídica, aterosclerose

\section{ABSTRACT}

Cardiovascular diseases are the leading causes of death globally. The purpose of the article is to reveal the forms of anion exchangers with groups of ammonium and phosphoniumbases, which are the most promising for selective extraction of low- and very-low-density lipoprotein cholesterol (LDL and VLDL), their increased content beinga risk factor of circulatory system diseases. This research is of practical importance considering insufficient selectivity and side effects of commercial sorbents. The main method applied is a 
screening of a number of sorbents by sorption parameters of lipid profile components to reveal optimum samples for LDL and VLDL removal. We carried out a comparative analysis of sorption characteristics by the components of lipid profile for anion exchangers with groups of onium bases (ammonium and phosphonium) in three forms: hydroxyl, chloride, and bicarbonate. Sorbent capacity for lipid profile components (up to 5.65 $\mu \mathrm{mol} / \mathrm{g}$ by LDL and VLDL), as well as sorption efficiency factors, were found (LDL and VLDL selectivity coefficient was up to 6.06). The ability of sorbents to influence plasma atherogenicity was characterized. The most promising forms of anion exchangers for the selective sorption of lipids were defined: in general, these were $\mathrm{OH}$-forms. A sorbent with ammonium base groups has higher sorption capacity, and a sorbent with phosphonium base groups has a higher selectivity for atherogenic LDL and VLDL. The data of the article may be useful in the development and practical application of sorption columns for selective removal of LDL and VLDL cholesterol with minimal side effects.

Keywords: plasma sorption, plasma sorbents, cholesterol sorption, selective removal of cholesterol, lipid sorption, atherosclerosis

\section{АННОТАЦИЯ}

Актуальность исследуемой проблемы обусловлена лидирующей позицией сердечно-сосудистых заболеваний среди причин смертности в мире. Цель статьи заключается в определении форм анионитов с группами ониевых оснований, наиболее перспективных для селективного извлечения из плазмы холестерина липопротеидов низкой и очень низкой плотности (ЛПНП и ЛПОНП), повышенное содержание которого является фрактором риска болезней системы кровообращения. Данное исследование имеет практическую значимость ввиду недостаточной селективности и наличия побочных эфрфектов у сорбентов, применяемых в медицине в настоящее время. Ведущим методом исследования данной проблемы является скрининг ряда сорбентов по показателям сорбции компонентов липидного спектра, позволяющий выявить оптимальные образцы для удаления холестерина ЛПНП и ЛПОНП. В работе проведен сравнительный анализ сорбционных характеристик по компонентам липидного спектра для анионитов с группам иониевых оснований (аммониевого и фосфониевого) в трёх фрормах: гидроксильной, хлоридной и бикарбонатной. Найдены емкости сорбентов по компонентам липидного спектра (до 5,65 мкмоль/г по холестерину ЛПНП и ЛПОНП), а также показатели эффективности сорбции (коэффициент селективности к ЛПНП и ЛПОНП до 6,06). Охарактеризована способность сорбентов влиять на атерогенность плазмы. Определены наиболее перспективные формы анионитов для сорбции каждой фрракции липидного спектра: в основном это ОН-фрормы для обоих сорбентов. Показано, что сорбент с группами аммониевого основания обладает большей сорбционной способностью, асорбент с группами фоссрониевого основания - большей селективностью по отношению к атерогенным липопротеидам низкой и очень низкой плотности. Рассмотрены особенности сорбции и предполагаемое образование комплексов сорбируемых молекул холестерина и триглицеридов с сорбентом с позиции их химического строения. Материалы статьи могут быть полезными при разработке и внедрении в клиническую практику сорбционных колонок для селективного удаления холестерина ЛПНП и ЛПОНП с минимумом побочных эффектов.

Ключевые слова: плазмосорбция, плазмосорбенты, сорбция холестерина, селективная сорбция ЛПНП, сорбция липидов, атеросклероз

\section{INTRODUCTION}

According to Rosstat, blood circulatory system diseases have been the main causes of death in the Russian Federation during the last decade. The most frequent reason for these diseases is the increased content of low-density and very-low-density lipoprotein cholesterol (LDL and VLDL) in blood plasma. In the normal condition, the body maintains the stable level of cholesterol due to a complex of homeostatic mechanisms including etherification, biosynthesis, and endocytosis of this component. However, its high concentration is toxic for cells (lqbal et al., 2008; Kiss and Sniderman, 2017) Literature data show that inflammatory processes are often observed in patients on hemodialysis, and uremic toxins can be more important in 
atherosclerosis development than such standard risk factors as disturbance of lipid exchange, increased blood pressure, excess weight and smoking (Ronco et al., 2007; Rosales et al., 2015). The experiments in animals allowed assuming that high cholesterol level can damage the glomerular apparatus (Daugirdas et al., 2015). Hypersecretion by the liver of apoliprotein $\mathrm{B}$, the main protein component of VLDL, or its insufficient release from plasma can also increase the risk of atherosclerosis development (Fisher et al., 2014).

The modern technology of hyperlipidemia treatment by exchange transfusion of donor plasma, as well as by extracorporeal cleaning of autoplasma with its synchronous transfusion is quite suitable. At present, the tried and tested medical aspects of the technology allow to successfully perform exchange transfusion and extracorporeal plasma correction, with multiple degrees of patient protection thus significantly facilitating the use of these methods in medical practice (Abramyan, 2007; Schwartz et al.,. 2013). Alongside with LDL and VLDL direct removal from plasma, the methods of solid-phase extraction of useful high-density lipoprotein (HDL) followed by its subsequent elution can be applied for preparing plasma enriched with HDL. The monograph (Telepchak et al., 2004) describes the conditions for the extraction of lipids of various classes from serum with a high yield and degree of cleaning (Han, 2016). Lipid profile normalization is also one of the main clinical effects of online hemodiafiltration method (Karkar, 2016; Levy et al., 2016; Ronco et al., 2007). Cellulose triacetate membrane characterized by high-permeability of the diluted substances and antithrombogenicity allows to improve lipid metabolism and to reduce homocysteine level. Accumulation of the latter in the body damages the tunica intima thus resulting in multiple pathologies, including blood clots and atherosclerotic plaques formation (Nubé et al., 2016). During the last 30 years the convincing evidence that methods of therapeutic apheresis can successfully be used in cardiology to treat patients with lipid exchange disturbances, who are resistant to medicinal therapy, was obtained as mentioned in (Safarova and Afanas'eva, 2014). This treatment is highly effective and safe for the removal of atherogenic classes of lipoproteins and has to be used to stabilize atherosclerosis and improve the prognosis in patients with familial hypercholesterolemia and ischemic heart disease, refractory to conservative therapy.

However, the main components for the realization of such technologies (i.e., sorbents), are not numerous now and have insufficient adsorption capacity and selectivity for lipid profile components. At the same time, there are usually no interrelations between the structure and properties of a sorbent for complex sorption systems of lipids and a sorbent, even for lipoprotein molecules of the simplest structure. Development of selective sorbents is difficult to achieve now. In fact, affinity in the heterophase system is determined by strength and type of ionogenic groups, as well as by the parameters of a physical structure of a sorbent: the degree and type of crosslinks, porosity and the features of surface layers of three-dimensional copolymers with alternation of hydrophobic and hydrophilic sites. Thus, the only effective direction is a screening of a wide range of sorbents with varying properties.

In (Altynova et al., 2006), the authors showed that commercially available hemosorbents had no considerable advantage over plasma sorbents due to insufficient sorption capacity, low specificity or presence of fine particles. The use of selective hemosorbents does not currently resolve the main problem, i.e., the high cost of LDL-apheresis procedures in the treatment of patients with here dietary hypercholesterolemia.

In (Wang and $\mathrm{Yu}, 2013 ; \mathrm{Yu}, 2013$ ), the Chinese scientists studied various types of porous adsorbents on the basis of polystyrene, agarose and cellulose matrices binding LDL. They worked on the molecular recognition of pathogenic molecules by ligands. The extensive clinical practice of whole blood hemoperfusion in Chinese hospitals shows that this method is effective, safe and profitable.

Shablovsky and colleagues developed the method of obtaining coal hemosorbents with a wide range of functional groups enabling to extract hydrophobic metabolites of both the anionic and cationic nature from blood plasma. Methods of fluorescent probing and biochemical analysis showed that sorbents on the basis of Purolite ion-exchange resin had high deliganding properties, especially in relation to neutral and cationic hydrophobic metabolites. The fact that the sorbents have practically no influence on total protein and albumin content make them safe for plasma sorption (Shablovskiy et al., 2009). 
The patent (Furuyoshi and Tani, 1989) offers a method for obtaining the sorbent with the amino groups having substitutes with the aromatic ring extracting LDL and VLDL due to electrostatic and hydrophobic interactions. The authors carried out the synthesis by immobilization of aniline, benzylamine, benzoic acid and p-nitrobenzoic acid on the cellulose and agarose gels treated with epichlorohydrin. Aromatic rings were shown to considerably increase affinity as well as selectivity of a sorbent for atherogenic lipoproteins.

In (Korolik et al., 2011), it is stated that when maximum diet therapy and medical therapy are not effective, the DALI LDL-apheresis system might be recommended for wide clinical use with the purpose of quick and safe correction of lipid exchange disturbances.

Agishi and coauthors (1994) published data on the use of the Liposorber LA-15 system for LDL-apheresis in the treatment of coronary and peripheral vascular diseases associated with severe hypercholesterolemia. The system consists of three main components forming the closed extracorporeal circuit: the unit for plasma separation Sulflux FS-05, Liposorber LA-15 columns for LDL adsorption and the apheresis unit MA-01 for monitoring and control of plasma separation and adsorption-desorption. The system selectively extracts lipoproteins containing apoliprotein B including LDL, VLDL, and lipoprotein (a).

The LDL continuous apheresis system with automatic regeneration of a dextran sulfate cellulose column is described in (Mabuchi et al., 1987). The authors used two columns containing $150 \mathrm{ml}$ of a sorbent. The total amount of the circulating plasma was $400 \mathrm{ml}$. After $600 \mathrm{ml}$ of plasma had passed over the first column, the second column was used, while the first column was regenerating. Thus, alternate use of two columns allowed maintaining the efficiency of the unit. Control was maintained by means of the computerized unit that excluded the necessity of the additional manipulations used in an ordinary method with one column. In processing 4-5 I of plasma LDL and VLDL levels decreased by 63$71 \%$, whereas HDL level remained unchanged. This method is applicable to the treatment of patients with familiar hypercholesterolemia and severe coronary heart disease.

Bambauer (2002) described clinical results of LDL apheresis obtained by different methods. Four systems of LDL apheresis were studied: dextran sulfate adsorption (Liposorber, Kaneka), immunoadsorption (Therasorb, Baxter), LDL hemoperfusion (Dali, Fresenius) and the immunoabsorption system with special antilipoprotein (a) columns (Lipopak, Pocard). The authors showed high efficiency of LDL apheresis of all four methods, and clinical results had no significant differences. Before LDL apheresis lipoprotein mean levels in patients were as follows (mg/dl): total cholesterol was equal to

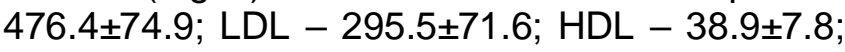
triglycerides - 508.2 \pm 212.8 ; lipoprotein (a) $52.4 \pm 11.3 ; \quad$ fibrinogen $-273.2 \pm 46.7$ and $472.8 \pm 121.2$. After the general period of LDL apheresis studies $(84.9 \pm 43.2$ months) the mean decrease in values (\%) was as follows: total cholesterol was equal to 50.6; LDL - 52.2; lipoprotein (a) - 64.3; triglycerides - 43.1; apoliprotein $B-39.5$; fibrinogen - 26.7.

In (Kobayashi et al., 2002), the authors carried out the analysis of dextran sulfate cellulose sorption material of nearly the same chemical structure as an adsorbent in Liposorber LA-15/LA-40 systems, but with larger particle size. In all the blood perfusion experiments this material extracted atherogenic LDL cholesterol, the concentration of HDL cholesterol remaining practically unchanged. When using fresh human donor blood or bovine blood to which acidic citrate dextrose or sodium citrate was added as a coagulant, the adsorbent revealed minimum side effects concerning activation and loss of blood cells thus showing its good hemocompatibility. Besides, the adsorbent had mechanical stability and did not cause hemolysis. In a series of experiments, adsorbent removed more than $25 \%$ of triglycerides and LDL.

German scientists conducted in vitro studies of the efficacy and biocompatibility of LDL absorber in the course of lipid apheresis by hemoperfusion (Bosch et al., 1993). The adsorbent represented the modified polyacrylate gel immobilized on a solid support. The absorber revealed the ability to selectively remove LDL particles from the whole blood. In vitro experiments showed quantitative adsorption of atherogenic LDL cholesterol and low nonspecific removal of useful HDL cholesterol. The obvious advantage of such hemoperfusion over plasmapheresis is the absence of an extra stage of plasma separation. This reduces the cost of the extracorporeal circuit and significantly simplifies its use.

Another work (Bosch et al., 2006) reviews 
direct adsorption of LDL (DALI), whose main advantage is simplicity and convenience of use. Extracorporeal circuit consisted only of sterile disposable expendables. To decrease LDL cholesterol content for at least $60 \%$ per session, the authors used four different configurations: DALI 500, 750, 1000 and $1250.96 \%$ of the sessions showed no complications. However, some patients complained of such side effects as hypotension and paresthesia, especially during the initial sessions. Mean decrease in concentration per one session constituted (\%) as follows: $69 \pm 12$ for LDL cholesterol; $41 \pm 18$ for triglycerides; $15 \pm 10$ for HDL cholesterol; $19 \pm 11$ for fibrinogen; and $62 \pm 24$ for lipoprotein (a) (in patients with a concentration of lipoprotein (a) more than $30 \mathrm{mg} / \mathrm{dl}$ ).

Cheng Y. and others studied amphiphilic adsorbent for LDL removal in vitro and in vivo. The adsorbent was prepared using a technique described in (Wang et al., 2002). The authors studied the effects of sulfonation and grafting time of cholesterol on the swelling property of adsorbent. When these parameters were 3 and 5 $\mathrm{h}$, respectively, the amphiphilic adsorbent had a high adsorption capacityfor LDL without significant $\mathrm{HDL}$ adsorption. The adsorption capacity for LDL, total cholesterol, and triglycerides was 1.916, 2.132, $1.349 \mathrm{mg} / \mathrm{ml}$, respectively. Experiments in rabbits with hyperlipidemia fed with fodder enriched with cholesterol or yolks were performed. After $2 \mathrm{~h}$ hemoperfusion, the LDL levels decreased from $3.619 \pm 0.354$ to $0.724 \pm 0.07 \mathrm{mmol} / \mathrm{l}$ showing that the adsorbent was capable of effectively removing LDL without side effects (Cheng et al., 2003).

Li H. and colleagues (2004) studied synthesis and LDL adsorption for hemocompatible crosslinked macroporous copolymers. The synthesis was carried out by suspension polymerization of vinylacetate and triallylisocyanurate with the subsequent transformation in a copolymer of vinyl alcohol and triallylisocyanurate. Then epoxidation was carried out through the reaction of epichlorohydrin with a copolymer hydroxyl group. Further carboxyl groups were immobilized through 1.6hexanediamine or thriethylenetetramine or attached directly to the copolymer hydroxyl group. The adsorption capacities of the obtained sorbents were $(\mathrm{mg} / \mathrm{g})$ as follows: $0.78-2.70$ for total cholesterol; 0.24-0.66 for HDL cholesterol; 0.54-2.04 for LDL and VLDL cholesterol. The selectivity defined as the ratio of capacities for
(LDL+VLDL)/HDL was 1.76-3.09.

Koga and others (1999) studied long-term effects of LDL apheresis influencing the course of carotid atherosclerosis in patients with familial hypercholesterolemia. Two groups of patients with familial hypercholesterolemia were examined, i.e., two homozygous and nine heterozygous patients who received the combined treatment of LDL apheresis and medicinal therapy to decrease the LDL level for a mean of 7.8 years. The mean treatment period for the control group of 10 heterozygous patients was only 5.5 years. As a result of LDL apheresis, the LDL cholesterol level decreased from $16.0 \pm 3.60$ to $6.43 \pm 0.07 \mathrm{mmol} / \mathrm{l}$ in homozygous patients and from $11.5 \pm 2.46$ to $4.32 \pm 1.2 \mathrm{mmol} / \mathrm{l}$ in heterozygous ones. During the long-term treatment, the existing plaques tended to increase, and new ones were formed in the carotid artery in both groups.

\section{MATERIALS AND METHODS}

Previously, we investigated a wide range of sorbents of various classes: cation and anion exchangers, polyampholytes, neutral sorbents, and active coals, specific sorbents. Sorbents good at extracting lipoproteins were shown to be the most numerously presented by a group of anionites. Anionite AMX-1 was studied in three ionic forms: hydroxyl, bicarbonate, and chloride. The use of various forms allows varying hydrophilicity-hydrophobicity of onium groups influencing the sorption of bipolar lipids. Further, it was interesting to compare the sorption of lipid profile components by forms of two anion exchangers with the groups of quaternary onium bases: ammonium (AMX-1) and phosphonium (QP quaternary phosphonium) base and determine the most promisinganion exchanger type and a form for LDL and VLDL extraction.

The sample of AMX-1 taken for analysis represents anion exchanger on the basis of chloromethylated styrene-divinylbenzene copolymer $(10.1 \%$ of chlorine, $30 \%$ of divinylbenzene, $115 \%$ of isooctane, the specific surface area $-110 \mathrm{~m}^{2} / \mathrm{g}$, the total pore volume $1.5 \mathrm{~cm}^{3} / \mathrm{g}$, porosity - 52\%), modified by monoethanolamine (synthesized by A. I. Zorina, All-Russian Research Institute of Chemical Technology). The QP sorbent is a macroporous phosphorylated styrene-divinylbenzene copolymer 
with quaternary tripropylphosphonic groups.

The studied sorbents have the following formulae, as in Equation 1.

Positively charged nitrogen and phosphorus atoms interact with negatively charged parts of the sorbed molecules of cholesterol and triglyceride presented in all lipoprotein fractions (but mostly in chylomicrons and VLDL), triglyceride and esterified cholesterol being contained in the core of the particle and non-esterified cholesterol being on its surface (Hussain, 2014; lqbal et al., 2014; lqbal and Hussain, 2009; Klimov and Nikul'cheva, 1999).

Figure 1 shows the structural formulae of cholesterol and triglyceride. The highest electron density is concentrated on oxygen atoms of both molecules, thus providing their affinity to anion exchangers with the groups of the onium bases.

It is possible to assume that complexes are formed according to reaction schemes 1, 2 for the sorption on AMX-1 anion exchanger (the reactions are similar for QP sorbent).

The experimental method consisted in keeping the sorbents in contact with plasma for the extraction of different components from it. Then the analyses of initial plasma and plasma after sorption were performed in the licensed laboratory In vitro. The content of triglycerides, total cholesterol, HDL, LDL, and VLDL was determined.

Automatic biochemical analyzer Architect c8000 was used. The methods of determination are presented in Table 1.

Sorption capacity was calculated as Equation 2:

$m=\left(C_{0}-C_{f}\right) V / g$,

where

m - sorption capacity, $\mu \mathrm{mol} / \mathrm{g}$;

$\mathrm{C}_{0}$ - initial concentration, $\mathrm{mmol} / \mathrm{l}$;

$\mathrm{C}_{f}-$ final concentration, $\mathrm{mmol} / \mathrm{l}$;

$\mathrm{V}$ - volume of plasma, $\mathrm{ml}$;

$g$ - sorbent mass per dry weight.

\section{RESULTS AND DISCUSSION}

in Table 2.

The results of the analyses are presented

Columns 3-7 contain data on sorption capacities for lipid profile components: triglycerides (TG), total cholesterol (TC), highdensity lipoprotein cholesterol (HDL), low- and very-low-density lipoprotein cholesterol (LDL and VLDL).

On the basis of these values, the following parameters have been calculated characterizing a complex effect of sorbents on several components, as well as selectivity of extraction of certain components or a complex of several components of lipid profile.

Capacity for LDL and VLDL, $\mu \mathrm{mol} / \mathrm{g}$ (column 8):

$m(L D L+V L D L)=m(L D L)+m(V L D L)$

Capacity for LDL, VLDL and TG, $\mu \mathrm{mol} / \mathrm{g}$ (column 9):

$$
\begin{gathered}
m(L D L+V L D L+T G)=m(L D L)+m(V L D L)+m(T G) \\
(\text { Eq. } 4)
\end{gathered}
$$

The relation of capacities $\mathrm{m}(\mathrm{LDL}) / \mathrm{m}(\mathrm{HDL})$ (column 10).

The selectivity coefficient equal to the relation of capacities $\mathrm{m}(\mathrm{LDL}+\mathrm{VLDL}) / \mathrm{m}(\mathrm{HDL})$ (column 11).

The relation of capacities $\mathrm{m}(\mathrm{LDL}+\mathrm{VLDL}+\mathrm{TG}) / \mathrm{m}(\mathrm{HDL})$ (column 12).

To characterize the atherogenic properties of plasma that underwent sorption, we calculated the following parameters:

- the atherogenic index $\left(\mathrm{K}_{1}\right.$, column 13$)$ is equal to the relation of LDL concentration to HDL concentration;

- the atherogenic coefficient $\left(K_{2}\right.$, column 15$)$ is equal to the relation of LDL+VLDL concentration to HDL concentration;

- the elation of concentration (LDL+VLDL+TG)/HDL (K $\mathrm{K}_{3}$, column 17).

The percentage of change was calculated for each of these parameters to evaluate the 
influence of sorbents on plasma atherogenicity (columns 14, 16, 18):

$$
\delta K_{i}=\left(K_{i} / K_{i 0}-1\right) \times 100,
$$

where $\mathrm{K}_{\mathrm{i}}-\mathrm{K}_{1}, \mathrm{~K}_{2}, \mathrm{~K}_{3}$ parameters for plasma which underwent sorption;

$\mathrm{K}_{\mathrm{i} 0}-\mathrm{K}_{1}, \mathrm{~K}_{2}, \mathrm{~K}_{3}$ parameters for initial plasma.

Positive percentage of change means that the parameter has increased and, respectively, plasma has become more atherogenic. Negative percentage of change means otherwise.

Apparently, the capacity of AMX-1 for lipoproteins was higher than that of $\mathrm{QP}$ in all three forms. Probably, it can be explained by a steric factor: a quaternary atom of phosphorus in QP molecule is shielded by three voluminous propyl substitutes, while the nitrogen atom in AMX-1 has hydrogens as two of four substitutes making it significantly easier to reach by the sorbed components. Among various forms of one sorbent, both for AMX-1 and QP, the greatest sorption is typical of the hydroxyl form, followed by the chloride form. The bicarbonate form has the smallest sorption. HDL fraction is an exception, being absorbed slightly better by bicarbonate forms, than by chloride ones. However, this difference is quite insignificant.

Total capacities for LDL+VLDL and for LDL+VLDL+TG are higher for AMX-1 anion exchanger, but QP in all three forms has a higher selectivity for LDL than AMX-1. Practically all the capacities and selectivity for LDL, LDL+VLDL and $\mathrm{LDL}+\mathrm{VLDL}+\mathrm{TG}$ improve in the row of an $\mathrm{HCO}_{3}$ form $<\mathrm{Cl}$-form $<\mathrm{OH}$-form for both sorbents. Exception: the selectivity for LDL+VLDL and LDL+VLDL+TG of AMX-1 increases in the row of $\mathrm{HCO}_{3}$-form $<\mathrm{OH}$-form $<\mathrm{Cl}$-form.

Despite having high adsorption capacities for each lipid profile component, AMX-1 in all three forms extracts a significant amount of useful HDL, deteriorating plasma by increasing its atherogenicity. On the contrary, the plasma atherogenicity is only slightly influenced by QP, which makes it safe from this point of view, though it has small capacities for LDL and VLDL.

\section{CONCLUSIONS:}

As a result of the study, the most promising forms of $\mathrm{AMX}-1$ and $\mathrm{QP}$ anion exchangers for the sorption of each lipoprotein fraction have been determined: generally, these are $\mathrm{OH}$-forms for both sorbents. The comparative analysis showed that AMX-1 has higher sorption capacity, and QP has a higher selectivity for LDL and VLDL. An explanation of peculiarities and distinctions in the sorption for the examined anion exchanger forms considering the structure of their functional groups was suggested. The results obtained could be a step forward to the improvement of plasma sorption methods for the treatment of cardiovascular diseases.

\section{ACKNOWLEDGMENTS}

The work was supported by the Mendeleev University of Chemical Technology of Russia, project number 017-2018.

\section{REFERENCES:}

1. Abramyan, M. V.; Opportunities of lipopheresis in the complex treatment of atherosclerosis, Kreativnaya kardiologiya 2007, 1-2, 208.

2. Agishi, T.; Wood, W.; Gordon, B.; LDL Apheresis Using the Liposorber $\AA^{\circledR}$ LA-15 System in Coronary and Peripheral Vascular Disease Associated with Severe Hypercholesterolemia, Current Therapeutic Research 1994, 55(8), 879.

3. Altynova, E. V.; Afanas'eva, O. I.; Boldyrev, A. G.; Potokin, I. L.; Sokolov, A. A.; Afanas'eva, M. I.; Pokrovskiy, S. N.; Hemosorbents for removal of atherogenic lipoproteins (in vitro comparison), Efferentnaya terapiya 2006, 12(4), 3.

4. Bambauer, R.; Low-Density Lipoprotein Apheresis: Clinical Results with Different Methods, Artif Organs 2002, 26(2), 133.

5. Bosch, T.; Gahr, S.; Belschner, U.; Schaefer, C.; Lennertz, A.; Rammo, J.; Direct Adsorption of Low-Density Lipoprotein by DALI-LDL-Apheresis: Results of a Prospective Long-term Multicenter Follow-up Covering 12291 Sessions, Ther Apher Dial. 2006, 10(3), 210.

6. Bosch, T.; Schmidt, B.; Blumenstein, M.; 
Gurland, H.-J.; Lipid Apheresis by Hemoperfusion: In Vitro Efficacy and Ex Vivo Biocompatibility of a New LowDensity Lipoprotein Absorber Compatible with Human Whole Blood, Artif Organs 1993, 17(7), 640.

7. Cheng, Y.; Wang, S.; Yu, Y.; Yuan, Y.; In Vitro, In Vivo Studies of a New Amphiphilic Adsorbent for the Removal of Low-Density Lipoprotein, Biomaterials 2003, 24(13), 2189.

8. Daugirdas, J. T.; Blake, P. G.; Ing, T. S., eds.; Handbook of Dialysis. Wolters Kluwer Health, 2015.

9. Fisher, E.; Lake, E.; Mcleod, R. S.; A polipoprotein B100 quality control and the regulation of hepatic very low density lipoprotein secretion, J. Biomed. Res. 2014, 28(3), 178.

10. Furuyoshi, S.; Tani, N.; Lipoprotein Adsorbent and Apparatus for Removing Lipoproteins Using the Same: patent 4,814,077 United States, 1989, appl. No. $12,232$.

11. Han, X.; Lipidomics. Comprehensive Mass Spectrometry of Lipids. Wiley: Orlando, Florida, 2016.

12. Hussain, M. M.; Intestinal Lipid Absorption and Lipoprotein Formation, Curr Opin Lipidol. 2014, 25(3), 200.

13. Iqbal, J.; Boutjdir, M.; Rudel, L. L.; Hussain, M. M.; Intestine-specific MTP and global ACAT2 deficiency lowers acute cholesterol absorption with chylomicrons and HDLs, J. Lipid Res. 2014, 55(11), 2261.

14. Iqbal, J.; Hussain, M. M.; Intestinal Lipid Absorption, Am. J. Physiol. Endocrinol. Metab. 2009, 296(6), E1183.

15. Iqbal, J.; Lawrence, L. R.; Hussain, M. M.; Microsomal Triglyceride Transfer Protein Enhances Cellular Cholesteryl Esterification by Relieving Product Inhibition, J. Biol. Chem. 2008, 283(29), 19967.

16. Karkar, A.; Advances in Hemofiltration. Exlibra, 2016.

17. Kiss, R. S.; Sniderman, A.; Shunts, channels, and lipoprotein endosomal traffic: new model of cholesterol homeostasis in the hepatocyte, $J$. Biomed. Res. 2017, 31(2), 95.

18. Klimov, A. N.; Nikul'cheva, N. G.; Metabolism of Lipids and Lipoproteins and Its Disorders, Piter Kom: Saint Petersburg, 1999.
19. Kobayashi, A.; Nakatani, M.; Furuyoshi, S.; Tani, N.; In Vitro Evaluation of Dextran Sulfate Cellulose Beads for Whole Blood Infusion Low-Density LipoproteinHemoperfusion, Ther Apher. 2002, 6(5), 365.

20. Koga, N.; Watanabe, K.; Kurashige, Y.; Sato, T.; Hiroki, T.; Long-Term Effects of LDL Apheresis on Carotid Arterial Atherosclerosis in Familial Hypercholesterolaemic Patients, Journal of Internal Medicine 1999, 246(1), 35.

21. Korolik, A. K.; Kirkovskiy, V. V.; Karchak, V. I.; Extracorporeal correction of dyslipidemia, Zdravookhraneniye 2011, 1, 60.

22. Levy, J.; Brown, E.; Lawrence, A.; Oxford Handbook of Dialysis. The Essential Guide to Dialysis and the Management of End Stage Kidney Disease. University Press: Oxford, 2016.

23. Li, H.; Zhang, Y.; Chen, X.; Shi, K.; Yuan, Z.; Liu, B.; Shen, B.; He, B.; Synthesis and Adsorption Aspect of Crosslinked PVA-Based Blood Compatible Adsorbents for LDL Apheresis, Reactive \& Functional Polymers 2004, 58(1), 53.

24. Mabuchi, H.; Michishita, I.; Takeda, M.; Fujita, H.; Koizumi, J.; Takeda, R.; Takada, S.; Oonishi, M.; A New Low Density Lipoprotein Apheresis System Using Two Dextran Sulfate Cellulose Columns in an Automated Column Regenerating Unit (LDL Continuous Apheresis), Atherosclerosis 1987, 68(1-2), 19.

25. Nubé, M. J.; Grooteman, M. P. C.; Blankestijn, P. J.; Hemodiafiltration. Theory, Technology and Clinical Practice. Springer, 2016.

26. Ronco, C.; Canaud, B.; Aljama, P.; Hemodiafiltration; Contributions to Nephrology, Karger Publ. 2007, 158, 211, 216, 219.

27. Rosales, L.; Thijssen, S..; Kruse, A.; Sipahioglu, M. H.; Hirachan, P.; Raimann, J. G.; Kuntsevich, V.; Carter, M.; Levin, N. W.; Kotanko, P.; Inflammatory Response to Sorbent Hemodialysis, ASAIO J. 2015, 61(4), 463.

28. Safarova, M. S.; Afanas'eva, O. I.; Application of lipoprotein apheresis in atherosclerosis and its complications, Ateroskleroz i dislipidemii 2014, 2, 5.

29. Schwartz, J.; Winters, J. L.; Padmanabhan, A.; Balogun, R. A.; 
Delaney, M.; Linenberger, M. L.; Szczepiorkowski, Z. M.; Williams, M. E.; $\mathrm{Wu}$, Y.; Shaz, B. H.; Guidelines on the Use of Therapeutic Apheresis in Clinical Practice - Evidence-Based Approach from the Writing Committee of the American Society for Apheresis, Journal of Clinical Apheresis 2013, 28(3), 145.

30. Shablovskiy, V. O.; Korolik, E. V.; Korolenko, E. A.; Tuchkovskaya, A. V.; Korolik, A. K.; Kazakov, F. I.; Kirkovskiy, V. V.; Ivashina, O. V.; Coal hemosorbents for extracorporeal blood purification and estimation of their efficiency by fluorescence sensing, Vestnik BGU 2009, 2(3), 10.

31. Telepchak, M. J.; August, T. F.; Chaney, G.; Forensic and Clinical Applications of Solid Phase Extraction. Humana Press: Totowa, New Jersey, 2004.

32. Wang, S. Q.; Yu, Y. T.; Cui, T.; Cheng, Y.; Cellulose Amphiphilic Adsorbent for the Removal of Low Density Lipoprotein, Artif Cells Blood Subs Immob Biotechnol. 2002, 30(4), 285.

33. Wang, Y.-J.; Yu, Y.-T.; Development of Resin Adsorbents for Blood Purification at Nankai University in China, Artificial Cells, Blood Substitutes, and Biotechnology 2011, 39(2), 92.

34. Yu, Y.-T.; Adsorbents in Blood Purification: From Lab Search to Clinical Therapy, Chinese Science Bulletin 2013, 58(35), 4357. 
Table 1. Methods of determination of lipid profile components

\begin{tabular}{ll}
\hline \multicolumn{1}{c}{ Component } & \multicolumn{1}{c}{ Method } \\
\hline Triglycerides & Enzymatic colorimetric (GPO PAP) \\
\hline Total cholesterol & Enzymatic, cholesterol esterase(CHOD-PAP) \\
\hline HDL cholesterol & Direct measurement following polyanionic adsorption of other lipoproteins \\
\hline LDL cholesterol & Calculation method (according to Fridvald's formula) \\
\hline VLDL cholesterol & Calculation method \\
\hline
\end{tabular}

Table 2. Sorption of lipid profile components by various forms of anion exchangers with onium base groups

\begin{tabular}{|c|c|c|c|c|c|c|c|c|c|c|c|c|c|c|c|c|c|}
\hline \multirow[b]{2}{*}{$\mathrm{N}$} & \multirow[b]{2}{*}{ Sorbent } & \multicolumn{7}{|c|}{$\mathrm{m}, \mu \mathrm{mol} / \mathrm{g}$} & \multirow[b]{2}{*}{ 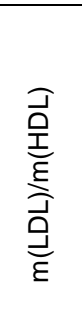 } & \multirow[b]{2}{*}{ 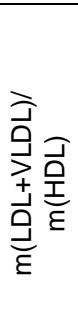 } & \multirow{2}{*}{ 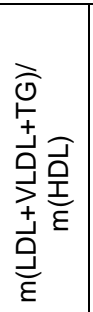 } & \multirow[b]{2}{*}{$\bar{y}$} & \multirow[b]{2}{*}{ 䓂 } & \multirow[b]{2}{*}{$\approx$} & \multirow[b]{2}{*}{$\begin{array}{l}\stackrel{\circ}{\circ} \\
\text { 芒 }\end{array}$} & \multirow[b]{2}{*}{ 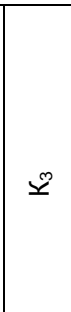 } & \multirow[b]{2}{*}{ 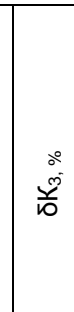 } \\
\hline & & $\stackrel{5}{\circ}$ & $\stackrel{O}{\bullet}$ & 全 & $\vec{a}$ & $\stackrel{\vec{\partial}}{\supset}$ & $\stackrel{\vec{\partial}}{\stackrel{\vec{J}}{\supset}}$ & 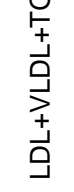 & & & & & & & & & \\
\hline 1 & 2 & 3 & 4 & 5 & 6 & 7 & 8 & 9 & 10 & 11 & 12 & \begin{tabular}{|l|}
13 \\
\end{tabular} & \begin{tabular}{|l|}
14 \\
\end{tabular} & 15 & \begin{tabular}{|l|}
16 \\
\end{tabular} & 17 & 18 \\
\hline 1 & AMX-1 (OH) & 3.15 & 7.90 & 2.24 & 4.19 & 1.47 & 5.65 & 8.80 & 1.87 & 2.52 & 3.92 & 5.7 & 26.7 & 7.4 & 26.1 & 11.3 & 25.7 \\
\hline 2 & AMX-1 (Cl) & 3.09 & 7.06 & 1.98 & 3.63 & 1.45 & 5.08 & 8.17 & 1.83 & 2.56 & 4.12 & 5.7 & 27.1 & 7.4 & 25.8 & 11.2 & 24.7 \\
\hline 3 & AMX-1 $\left(\mathrm{HCO}_{3}\right)$ & 2.87 & 6.79 & 2.01 & 3.42 & 1.37 & 4.79 & 7.66 & 1.70 & 2.39 & 3.82 & 5.5 & 22.4 & 7.2 & 21.5 & 10.8 & 20.7 \\
\hline 4 & $\mathrm{QP}(\mathrm{OH})$ & 2.02 & 3.21 & 0.45 & 1.84 & 0.91 & 2.75 & 4.77 & 4.06 & 6.06 & 10.5 & 4.5 & 1.0 & 5.9 & \begin{tabular}{|l|}
-0.3 \\
\end{tabular} & 8.8 & -1.8 \\
\hline 5 & QP (Cl) & 1.13 & 1.75 & 0.31 & 0.89 & 0.55 & 1.44 & 2.57 & 2.90 & 4.70 & 8.40 & 4.6 & 2.3 & 6.0 & 1.3 & 9.0 & 0.4 \\
\hline 6 & $\mathrm{QP}\left(\mathrm{HCO}_{3}\right)$ & 0.51 & 1.31 & 0.34 & 0.74 & 0.23 & 0.97 & 1.48 & 2.17 & 2.83 & 4.33 & \begin{tabular}{|l|}
4.6 \\
\end{tabular} & \begin{tabular}{|l|}
1.9 \\
\end{tabular} & 6.0 & 1.9 & 9.1 & 1.9 \\
\hline
\end{tabular}

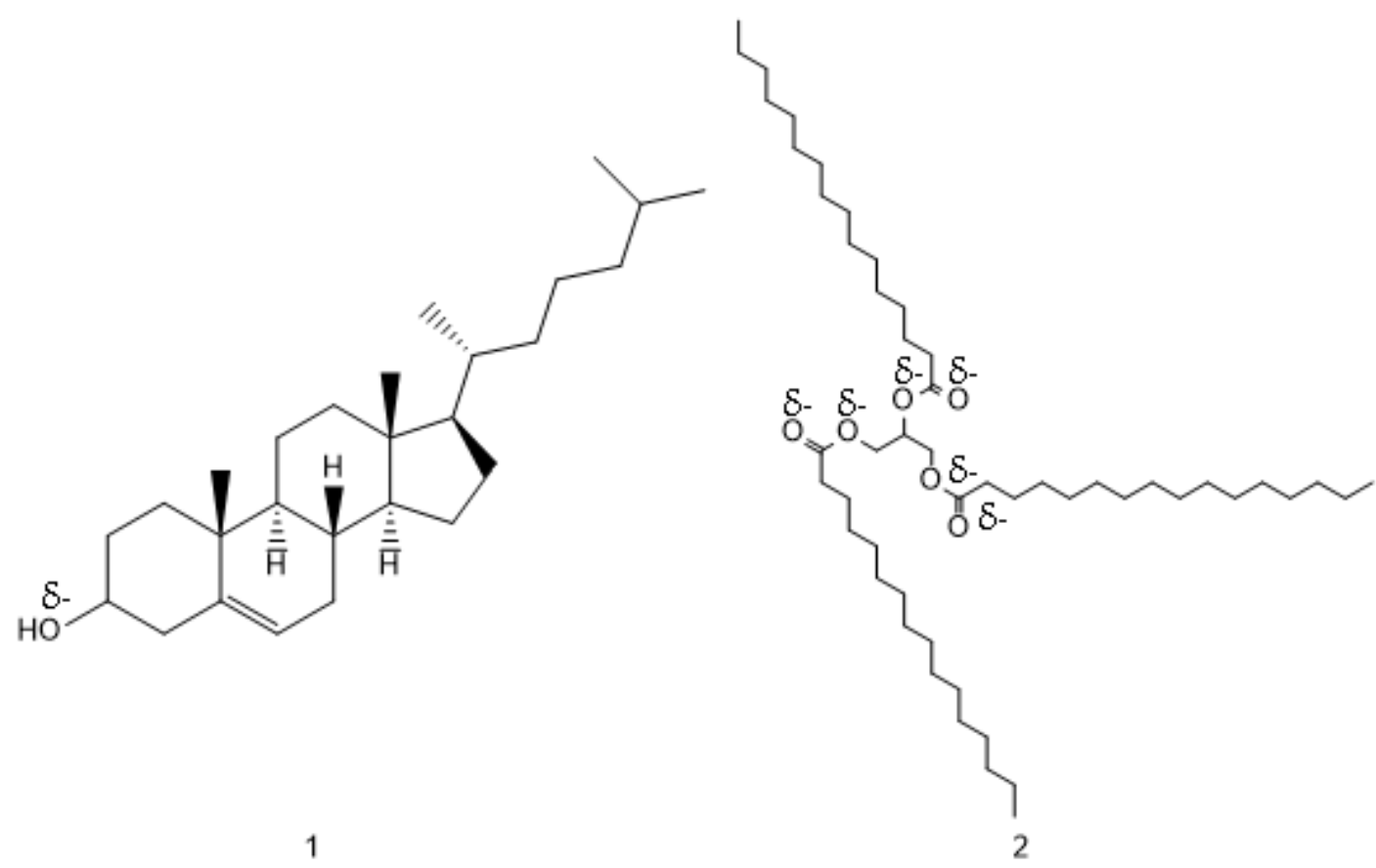

Figure 1. Structural formulae of sorbates: 1 - cholesterol, 2 - triglyceride 


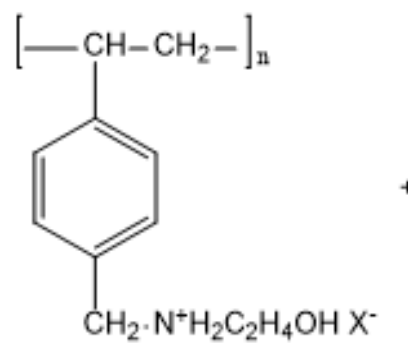<smiles>CC(C)CCCC(C)C1CCC2C3CC=C4CC(O)CCC4(C)C3CCC12C</smiles>

1

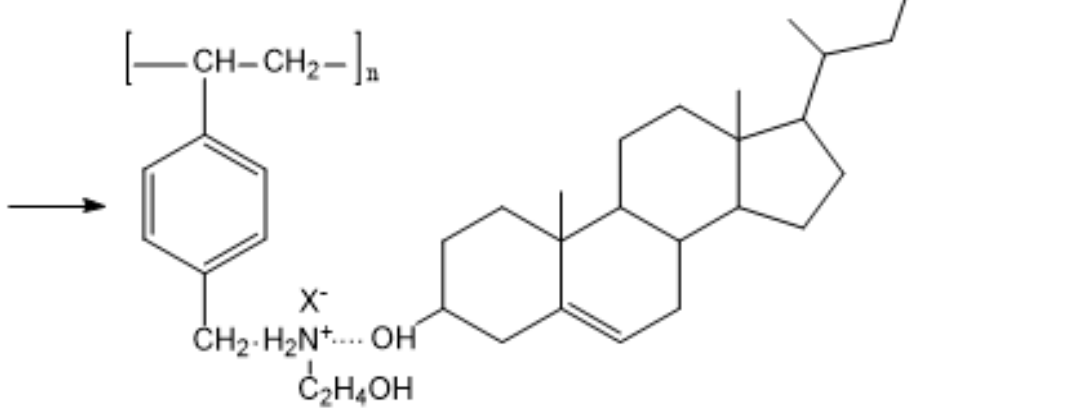

3

Scheme 1. Presumed reaction of complex (3) formation for the sorption of cholesterol (2) by $A M X-1$ anion exchanger (1) 


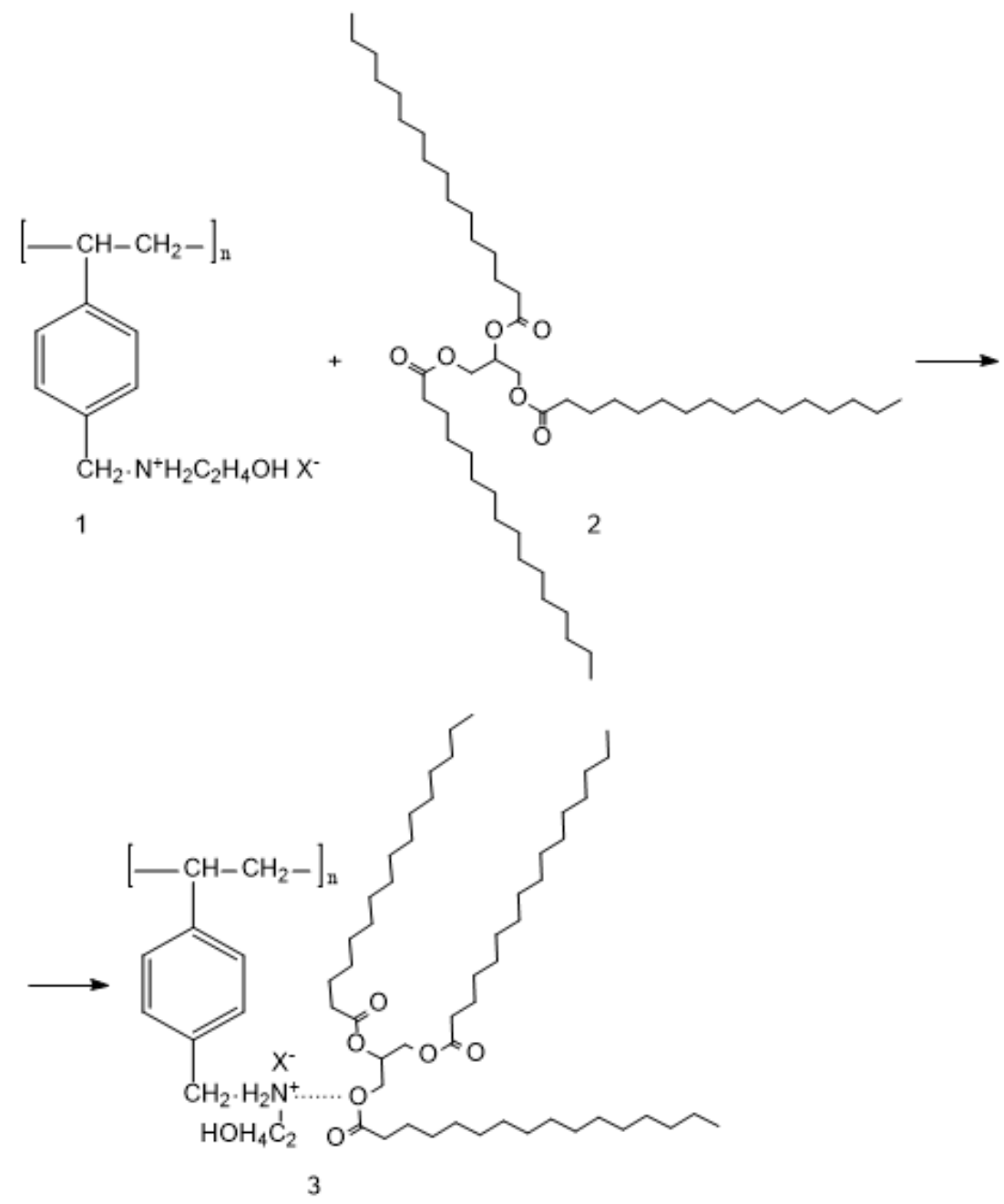

Scheme 2. Presumed reaction of complex (3) formation for the sorption of triglyceride (2) by $A M X-1$ anion exchanger(1)

\section{Equation 1}

AMX-1: [Pol- $\left.-\mathrm{N}^{+} \mathrm{H}_{2} \mathrm{C}_{2} \mathrm{H}_{4} \mathrm{OH}\right][\mathrm{X}]^{-}$

QP: $\left[\mathrm{Pol}-\mathrm{P}^{+}\left(\mathrm{C}_{3} \mathrm{H}_{7}\right)_{3}\right][\mathrm{XX}$,

where $[\mathrm{X}]^{-}=\mathrm{OH}, \mathrm{Cl}^{-}$or $\mathrm{HCO}_{3}^{-}$

PERIÓDICO TCHÊ QUÍMICA•www.periodico.tchequimica.com• Vol. 16 N. 31.

- ISSN 1806-0374 (impresso) • ISSN 1806-9827 (CD-ROM)・ISSN 2179-0302 (meio eletrônico) (C) 2019. Porto Alegre, RS. Brasil 